\title{
Kuning Telur Ayam Kampung Dapat Digunakan Sebagai Emulsifier Minyak Cengkeh untuk Bahan Anestetik pada Ikan Komet
}

\author{
(EGG YOLK OF KAMPONG CHICKEN CAN BE USED \\ AS CLOVE OIL EMULSIFIER FOR ANESTHETIC IN GOLDFISH) \\ Deo Lauda Putra ${ }^{1}$, I Gusti Ngurah Sudisma ${ }^{2}$ I Wayan Wirata ${ }^{2}$ \\ ${ }^{1}$ Mahasiswa Sarjana Pendidikan Dokter Hewan, \\ ${ }^{2}$ Laboratorium Ilmu Bedah Veteriner \\ Fakultas Kedokteran Hewan, Universitas Udayana \\ Jl. Sudirman, Sanglah, Denpasar Bali, Indonesia 80234 \\ Telp/fax. 0361-223791; Email: sudisma@unud.ac.id
}

\begin{abstract}
ABSTRAK
Penelitian ini bertujuan untuk mengetahui efektivitas campuran minyak cengkeh dengan kuning telur ayam kampung sebagai anestetik pada ikan komet (Carassius auratus auratus). Objek penelitian yang digunakan adalah 36 ekor ikan komet, berukuran $10 \pm 5 \mathrm{~cm}$, bobot badan 15-25 g, dan diberi pakan pellet. Data pada penelitian ini diperoleh dengan mencatat lama waktu teranestesinya ikan. Hewan coba dibagi menjadi sembilan kelompok perlakuan yaitu: perlakuan I (minyak cengkeh 100 ppm), perlakuan II (minyak cengkeh 100 ppm + etanol 96\% $1 \mathrm{~mL} / \mathrm{L}$ ), perlakuan III (minyak cengkeh $100 \mathrm{ppm}+$ kuning telur $0,4 \mathrm{~mL} / \mathrm{L}$ ), perlakuan IV (minyak cengkeh $100 \mathrm{ppm}+$ kuning telur $0,6 \mathrm{~mL} / \mathrm{L}$ ), perlakuan V (minyak cengkeh $100 \mathrm{ppm}+$ kuning telur 0,8 mL/L), perlakuan VI (minyak cengkeh $100 \mathrm{ppm}+$ kuning telur $1 \mathrm{~mL} / \mathrm{L}$ ), perlakuan VII (minyak cengkeh $100 \mathrm{ppm}+$ kuning telur 1,2 mL/L), perlakuan VIII (minyak cengkeh 100 ppm + kuning telur 1,4 mL/L), perlakuan IX (minyak cengkeh 100 ppm + kuning telur 1,6 mL/L). Masingmasing perlakukan dilakukan pengulangan sebanyak empat kali. Data yang diperoleh dianalisis dengan sidik ragam dan dilanjutkan dengan uji jarak berganda Duncan. Berdasarkan hasil penelitian diperoleh bahwa masing-masing kelompok perlakuan menunjukkan waktu induksi berbeda nyata $(\mathrm{P}<0,05)$ sedangkan waktu durasi dan waktu pemulihan tidak berbeda nyata $(\mathrm{P}>0,05)$. Induksi anestesi pada ikan komet dengan waktu induksi tercepat adalah 3,05 \pm 0,32 menit menggunakan kombinasi minyak cengkeh 100 ppm + kuning telur 1,6 mL/L.
\end{abstract}

Kata kata kunci: ikan komet; anestesi; minyak cengkeh; kuning telur

\begin{abstract}
This study aims to determine the effectiveness of a mixture of clove oil and kampong chicken egg yolk as an anesthetic in goldfish (Carassius auratus auratus). The research objects used in this study were 36 comet fish measuring $10 \pm 5 \mathrm{~cm}$, body weight $15-25 \mathrm{~g}$, and were fed pellets. The data were obtained by recording the length of time the fish was anesthetized. The experimental animals were divided into nine groups: Group I (100 ppm Clove Oil), Group II (Clove Oil 100 ppm + 96\% Ethanol 1ml/L), Group III (Clove Oil 100 ppm + $0.4 \mathrm{~mL} / \mathrm{L}$ egg yolk), Group IV (Clove Oil 100 ppm + egg yolk $0.6 \mathrm{~mL} / \mathrm{L})$, Group V (100 ppm Clove Oil + $0.8 \mathrm{~mL} / \mathrm{L}$ egg yolk), Group VI (Clove Oil 100 ppm + Egg yolk $1 \mathrm{~mL} / \mathrm{L}$ ), Group VII (Clove Oil 100 ppm + Egg yolk $1.2 \mathrm{~mL} / \mathrm{L}$ ), Group VIII (100 ppm Clove Oil + 1.4 mL/L Egg Yolk), Group IX (100 ppm Clove Oil + 1.6 mL/L Egg Yolk). Each group was repeated four times. Data that has been obtained analyzed with analysis of variance (ANOVA) and continued with the Duncan multiple range test. The result shows that the induction time was significantly different $(\mathrm{P}<0.05)$, while the duration and recovery time were not significantly different $(\mathrm{P}>0.05)$. The combination of clove oil and egg yolk can accelerate the induction of anesthesia with the fastest time being $3.05 \pm 0.32$ minutes with a combination dose of 100 ppm Clove Oil + Egg Yolk $1.6 \mathrm{~mL} / \mathrm{L}$.
\end{abstract}

Keywords: Gold Fish; anesthesia; clove oil; egg yolk 


\section{PENDAHULUAN}

Usaha perikanan terutama ikan hias air tawar merupakan alternatif usaha untuk meningkatkan perekonomian. Konsumen membeli ikan hias dengan harga yang lebih tinggi dibandingkan dengan ikan konsumsi. Salah satu ikan hias yang banyak dibudidayakan adalah ikan komet (Carassius auratus auratus). Ikan komet merupakan ikan hias yang menarik, murah, serta selalu memberikan konsistensi hasil yang identik dengan induknya (Gomelsky et al., 2011). Ikan komet merupakan salah satu jenis hias yang paling populer di dunia karena penampilannya yang beragam, seperti ukuran, bentuk tubuh, ciri sirip dan warnanya (Zhou et al., 2001; Moreira et al., 2011). Ikan komet tahan terhadap gangguan lingkungan dan gangguan antropogenik, dapat mentoleransi lingkungan dengan rentang suhu yang luas, kekeruhan air yang tinggi, dan oksigen rendah (Szczerbowski, 2002; Balon, 2004). Ikan komet juga produktif dan dewasa dengan cepat (Lorenzoni et al., 2010). Ikan komet hampir selalu tersedia di setiap penjual ikan hias dengan harga yang relatif murah dan stabil (Wahyuningsih et al., 2012).

Pada setiap usaha perikanan, khususnya usaha ikan komet memiliki berbagai kendala dan risiko. Salah satu kendala dalam budidaya ikan komet adalah penyakit (Kismiyati et al., 2012), dan salah satu tindakan dalam menangani penyakit pada ikan adalah pembedahan. Pada ikan, kemajuan dalam teknik bedah sudah banyak diterapkan. Pembedahan pada umumnya dilakukan untuk memotong tumor, memperbaiki cedera traumatis, atau memperbaiki buoyancy disorders (Harms, 2005). Beberapa tindakan pembedahan yang sudah berhasil dilakukan antara lain, tumor abdominal pada koi (Lewbart et al., 1998), swimbladde pada ikan cichlid, dan Cichlasoma citrinellum (Lewbart et al., 1995).

Penyebab tumor pada ikan yang banyak berkontribusi terhadap pembentukannya adalah virus, bahan kimia, racun biologis, agen fisik, hormon dan usia, jenis kelamin, kecenderungan genetik dan kompetensi imunologis (Spitsbergen et al., 2000; Roberts, 2012). Tindakan pembedahan dipilih sebagai solusi untuk mengatasi kejadian nekrosis dan pendarahan koagulatif, massa yang mengganggu aktivitas normal, mengalami ulserasi, dan hemoragik pada ikan (Murray, 2002). Pembedahan pada ikan yang paling sering dilaporkan dalam praktik klinis adalah sistem intergumen khususnya massa kulit (Brown et al., 2010). Menurut Bakal et al. (2005), pembedahan yang sering terjadi pada ikan yang mengikuti kejuaraan adalah enucleation. Pembedahan ini sering dilakukan karena hilangnya keindahan ikan.

Sebagian besar pembedahan pada ikan dilakukan di luar air, dengan keuntungan ahli bedah dapat melakukan operasi menggunakan teknik yang sama dengan yang digunakan pada hewan darat (Ross dan Ross, 1999). Sebelum melakukan oprasi pada ikan hal pertama yang dilakukan adalah menangkap dan mengangkut ikan, dalam hal ini ikan biasanya akan memberontak dan berdampak pada kesehatan dan pertumbuhannya. Untuk mengatasi masalah ini, dokter hewan telah menggunakan berbagai anestetik dalam upaya untuk mengurangi stres pada ikan (Perdikaris et al., 2010), dan untuk menjalani prosedur pembedahan mulai dari tagging, pengambilan sampel, dan insisi. Agen anestetik sangat diperlukan untuk memastikan kesejahteraan dan kelangsungan hidup ikan (Zahl et al., 2012). Langkah pertama dalam prosedur bedah yang sukses adalah membangun protokol anestesi yang aman dan efektif. Salah satu kriteria memilih obat anestetik antara lain seperti kemanjuran, biaya, ketersediaan, dan kemudahan penggunaan serta toksisitas terhadap ikan, dan lingkungan (Soto dan Burhanuddin, 1995; Akbulut et al., 2011).

Dewasa ini minyak cengkeh telah dipelajari potensinya sebagai suatu anestetik pada beberapa ikan dan beberapa spesies ikan air dingin dan hangat (Gomulka et al., 2008). Bahan aktifnya adalah eugenol (4-allyl2methoxyphenol) dan iso-eugenol (4-propenyl2-methoxyphenol), yang terdiri dari $90-95 \%$ dari berat minyak cengkeh. Eugenol cepat diserap dan dimetabolisme setelah pemberian oral pada anestesi ikan dan hampir sepenuhnya diekskresikan dalam urin dalam waktu 24 jam tanpa efek nyeri yang nyata pada ikan (Fischer et al., 1990). Menurut Guilderhus dan Marking (1987), anestesi yang efektif harus dapat membuat ikan pingsan dalam kurun waktu tiga menit, dan ikan harus pulih dalam 15 menit dalam air bersih.

Eugenol dalam hal ini adalah minyak cengkeh, ternyata sukar larut dalam air, untuk menyatukan antara air dan minyak diperlukan emulsifier. Banyak peneliti menggunakan alkohol atau deterjen sebagai emulsifier karena 
minyak cengkeh tidak mudah diemulsi dengan air tanpa agitasi yang kuat (Munday dan Wilson, 1997). Sering kali pelarut minyak itu sendiri yang berbahaya bagi kelangsungan hidup ikan. Lebih penting lagi, beberapa peneliti tidak menggunakan etanol atau deterjen karena biaya atau akses terbatas di lokasi lapangan terpencil (Munday dan Wilson, 1997).

Salah satu alternatif yang dapat digunakan sebagai emulsifier pada minyak cengkeh adalah kuning telur. Kuning telur sangat mudah didapatkan dan harganya murah. Winarno (1992) menjelaskan bahwa kuning telur merupakan pengemulsi yang lebih baik daripada putih telur karena kandungan lesitin pada kuning telur terdapat dalam bentuk kompleks sebagai lesitin-protein. Penggunaan kuning telur sebagai emulsifier minyak cengkeh untuk anestetik ikan komet belum banyak dilaporkan sebelumnya sehingga sangat baik untuk diteliti lebih lanjut. Tujuan penelitian ini yaitu untuk mengetahui dosis campuran antara minyak cengkeh dengan kuning telur sebagai anestetik serta mengetahui waktu induksi, durasi, dan pemulihan anestesi pada ikan komet.

\section{METODE PENELITIAN}

\section{Objek Penelitian}

Objek penelitian yang digunakan dalam penelitian ini adalah 36 ekor ikan komet $(C$ arassius auratus) sehat secara klinis yang dipelihara di Denpasar, Bali. Hewan yang digunakan berukuran $10 \pm 5 \mathrm{~cm}$ dengan berat badan 15-25 g. Hewan dikarantina dengan tujuan ikan dapat melakukan proses aklimasi terlebih dahulu selama dua hari. Semua $C$. auratus auratus diberikan makanan dua kali perhari berupa pakan pelet. Ikn komet dipelihara dalam aquarium berukuran $60 \times 41$ x $34 \mathrm{~cm}$ berkapasitas $60 \mathrm{~L}$, diisi dengan air mineral isi ulang dengan suhu air $29-31^{\circ} \mathrm{C}$ dan $\mathrm{pH}$ air 7-8. Ikan komet dibagi menjadi dua kelompok dan dipisah dalam dua kontainer.

\section{Rancangan Penelitian}

Rancangan penelitian yang digunakan pada penelitian ini ada rancangan acak lengkap (RAL). Pada penelitian ini, setiap perlakuan dilakukan pengulangan sebanyak empat kali, sehingga jumlah sampel yang digunakan adalah 36 ekor ikan komet. Setiap kelompok perlakuan dilakukan pemberian kombinasi minyak cengkeh (Cap Gajah 50 mL $^{\circledR}$, POM TR.
162691191, PT USFI, Surabaya, Indonesia) dan kuning telur ayam kampung yang dicampurkan dan ditambahkan air sebanyak $1 \mathrm{~mL}$. Kombinasi dosis perlakuan yang digunakan yaitu: Perlakuan 1 - minyak cengkeh (100 ppm); Perlakuan 2 - minyak cengkeh (100 ppm) + Etanol 96\% (1mL/L); Perlakuan 3 - minyak cengkeh $(100 \mathrm{ppm})+$ kuning telur $(0,4 \mathrm{~mL} / \mathrm{L})$; Perlakuan 4 - minyak cengkeh $(100 \mathrm{ppm})+$ kuning telur $(0,6 \mathrm{~mL} / \mathrm{L})$; Perlakuan 5 - minyak cengkeh $(100 \mathrm{ppm})+$ kuning telur $(0,8 \mathrm{~mL} / \mathrm{L})$; Perlakuan 6 - minyak cengkeh $(100 \mathrm{ppm})+$ kuning telur $(1 \mathrm{~mL} / \mathrm{L})$; Perlakuan 7 - minyak cengkeh (100 ppm) + kuning telur $(1,2 \mathrm{~mL} / \mathrm{L})$; Perlakuan 8 - minyak cengkeh $(100 \mathrm{ppm})+$ kuning telur (1,4 mL/L); Perlakuan 9 - minyak cengkeh $(100 \mathrm{ppm})+$ kuning telur $(1,6 \mathrm{~mL} / \mathrm{L})$

\section{Variabel Penelitian}

Variabel yang diukur yaitu waktu induksi, durasi, dan pemulihan. Variabel diukur sebelum diberikan perlakuan (menit ke-0), kemudian dilakukan pengukuran kembali setiap satu menit setelah diberikan agen anestesi. Waktu induksi adalah waktu yang dihitung dari awal pemberian anestetik (sebagai menit ke-0) sampai muncul efek anestesi (masuk ke stadium II) yang ditandai dengan mulai hilangnya reaktivitas terhadap rangsangan visual dan rangsangan tactile, hilangnya keseimbangan, tonus muskulus menurun. Waktu durasi adalah waktu lamanya hewan teranestesi yang ditandai dengan hilangnya kesadaran hewan dan kehilangan reaktifitas terhadap rangsangan eksternal. Waktu pemulihan adalah waktu kembalinya kesadaran dari efek obat anestesi yang ditandai dengan munculnya kembali gerak menghindar berenang hingga hewan aktif bergerak.

\section{Prosedur Penelitian}

Pemilihan Sampel Penelitian. Sampel yang digunakan pada penelitian ini adalah 36 ekor ikan komet (C. auratus auratus) dengan kondisi sehat. Kondisi tubuh C. auratus auratus ditinjau secara subjektif dan diamati cara ikan berenang.

Persiapan Penelitian. Pemeriksaan suhu air menggunakan termometer dan pengukuran $\mathrm{pH}$ air menggunakan $\mathrm{pH}$ meter dan pemeriksaan fisik dilakukan terhadap hewan coba sebelum perlakuan dimulai. Data yang diambil adalah rata-rata gerak operculum atau frekuensi pernapasan, pengukuran standard length yaitu panjang dari mulut sampai caudal peduncle, dan bobot badan. 
Teknik Anestesi. Minyak cengkeh dicampurkan dalam gelas dan ditambahkan beberapa mililiter air yang diambil dari wadah ikan yang sudah diukur lalu diaduk. Frekuensi respirasi (gerak operculum) dihitung sebelum hewan dianestesi. Hewan dimasukkan kedalam wadah yang berisi air dan campuran obat. Hewan dipastikan teranestesi dengan pengujian pinch test. Hewan diangkat dan diposisikan secara lateral dengan bantuan seorang asisten. Data yang diamati yaitu suhu lingkungan, muscle relaxation (jaw tone), pinch test (kulit dan ekor), dan righting reflex. Selanjutnya ikan komet kembali dimasukkan kedalam air bersih, selanjutnya ikan komet disentuh menggunakan pinset setiap 30 detik.

Pengambilan dan Analisis Data. Data yang diambil yaitu waktu induksi, durasi, dan pemulihan. Pengambilan data dilakukan dengan metode blind test. Dalam hal ini asisten yang mengambil data tidak mengetahui dosis yang diberikan dengan tujuan untuk mencegah placebo effect pada pengambilan data. Apabila dalam jangka waktu 30 menit ikan komet tidak menunjukkan reaksi terhadap anestesi, dosis tersebut dinyatakan tidak efektif bagi ikan komet dan pengambilan data dihentikan. Data yang diperoleh dianalisis dengan sidik ragam dan dilanjutkan dengan uji jarak berganda Duncan. Penelitian ini dilakukan pada bulan Agustus 2020 di Laboratorium Ilmu Bedah Veteriner, Fakultas Kedokteran Hewan, Universitas Udayana.

\section{HASIL DAN PEMBAHASAN}

Waktu induksi, durasi, dan pemulihan anestesi minyak cengkeh, kombinasi minyak cengkeh dan etanol 96\%, dan kombinasi minyak cengkeh dan kuning telur disajikan pada Tabel 1.

Berdasarkan hasil penelitian, waktu induksi anestesi perlakuan I berbeda nyata $(\mathrm{P}<0,05)$ terhadap perlakuan II sampai dengan perlakuan IX. Rerata waktu induksi perlakuan I sampai dengan IX secara berurutan yaitu $25,59 \pm 2,05 ; 4,84 \pm 0,46 ; 16,41 \pm 53,15 ; 3,06 \pm 0,32$; $3,60 \pm 0,37 ; 3,90 \pm 0,48 ; 3,58 \pm 0,42 ; 3,58 \pm 0,37$; $3,05 \pm 0,32$. Berdasarkan uji Duncan, Perlakuan I dan III berbeda nyata $(\mathrm{P}<0,05)$ terhadap kelompok perlakuan lain. Sedangkan P II, P IV, P V, P VI, P VII, P VIII, P IX tidak berbeda nyata antar kelompok perlakuan $(\mathrm{P}<0,05)$.

Berdasarkan hasil penelitian, durasi anestesi perlakuan I sampai dengan IX tidak berbeda nyata $(\mathrm{P}>0,05)$. Rerata waktu durasi anestesi perlakuan I sampai dengan IX secara berurutan yaitu $2,46 \pm 0,44 ; 1,38 \pm 0,11 ; 2,55 \pm 0,84$; $2,72 \pm 0,67 ; 2,75 \pm 0,32 ; 1,86 \pm 0,42 ; 2,68 \pm 2,53$; $2,36 \pm 0,43 ; 2,13 \pm 0,39$.

Waktu pemulihan anestesi perlakuan I sampai dengan VIII tidak berbeda nyata $(\mathrm{P}>0,05)$. Waktu pemulihan anestesi perlakuan IX berbeda nyata $(\mathrm{P}<0,05)$ terhadap kelompok perlakuan lainnya. Rerata waktu pemulihan anestesi perlakuan I sampai dengan IX secara berurutan yaitu $0,61 \pm 0,34 ; 1,09 \pm 0,31 ; 2,14 \pm 0,71$;

Tabel 1. Waktu induksi, durasi, dan pemulihan pada masing-masing kelompok perlakuan anastesi minyak cengkeh dan emulsifier kuning telur ayam kampung pada ikan komet

\begin{tabular}{lccc}
\hline Perlakuan & & Waktu (menit) & \\
\cline { 2 - 4 } & Induksi & Durasi & Pemulihan \\
\hline I $\left(\mathrm{C}_{100}\right)$ & $25,59 \pm 2,05^{\mathrm{d}}$ & $2,46 \pm 0,44^{\mathrm{a}}$ & $0,61 \pm 0,34^{\mathrm{a}}$ \\
II $\left.^{\mathrm{a}} \mathrm{C}_{100} \mathrm{E}_{96}\right)$ & $4,84 \pm 0,46^{\mathrm{b}}$ & $1,38 \pm 0,11^{\mathrm{a}}$ & $1,09 \pm 0,31^{\mathrm{a}, \mathrm{b}}$ \\
III $\left(\mathrm{C}_{100} \mathrm{~K}_{0,4}\right)$ & $16,41 \pm 53,15^{\mathrm{c}}$ & $2,55 \pm 0,84^{\mathrm{a}}$ & $2,14 \pm 0,71^{\mathrm{a}, \mathrm{b}}$ \\
IV $\left(\mathrm{C}_{100} \mathrm{~K}_{0,6}\right)$ & $3,06 \pm 0,32^{\mathrm{a}}$ & $2,72 \pm 0,67^{\mathrm{a}}$ & $0,57 \pm 0,37^{\mathrm{a}, \mathrm{b}}$ \\
V $\left(\mathrm{C}_{100} \mathrm{~K}_{0,8}\right)$ & $3,60 \pm 0,37^{\mathrm{a}, \mathrm{b}}$ & $2,75 \pm 0,32^{\mathrm{a}}$ & $0,40 \pm 0,10^{\mathrm{a}, \mathrm{b}}$ \\
VI $\left(\mathrm{C}_{100} \mathrm{~K}_{1}\right)$ & $3,90 \pm 0,48^{\mathrm{a}, \mathrm{b}}$ & $1,86 \pm 0,42^{\mathrm{a}}$ & $0,90 \pm 0,54^{\mathrm{a}, \mathrm{b}}$ \\
VII $\left(\mathrm{C}_{100} \mathrm{~K}_{1,2}\right)$ & $3,58 \pm 0,42^{\mathrm{a}, \mathrm{b}}$ & $2,68 \pm 2,53^{\mathrm{a}}$ & $0,77 \pm 0,55^{\mathrm{a}, \mathrm{b}}$ \\
VII $\left(\mathrm{C}_{100} \mathrm{~K}_{1,4}\right)$ & $3,58 \pm 0,37^{\mathrm{a}, \mathrm{b}}$ & $2,36 \pm 0,43^{\mathrm{a}}$ & $0,59 \pm 0,04^{\mathrm{b}}$ \\
IX $\left(\mathrm{C}_{100} \mathrm{~K}_{1,6}\right)$ & $3,05 \pm 0,32^{\mathrm{a}}$ & $2,13 \pm 0,39^{\mathrm{a}}$ & $0,61 \pm 0,72^{\mathrm{c}}$ \\
\hline
\end{tabular}

Keterangan: $\mathrm{C}=$ Minyak Cengkeh, $\mathrm{E}=$ Etanol, $\mathrm{K}=$ Kuning Telur. Huruf (superskrip) yang berbeda menunjukkan berbeda nyata $(\mathrm{P}<0,05)$. Sebaliknya, huruf (superskrip) yang sama menunjukkan tidak berbeda nyata $(\mathrm{P}>0,05)$. 


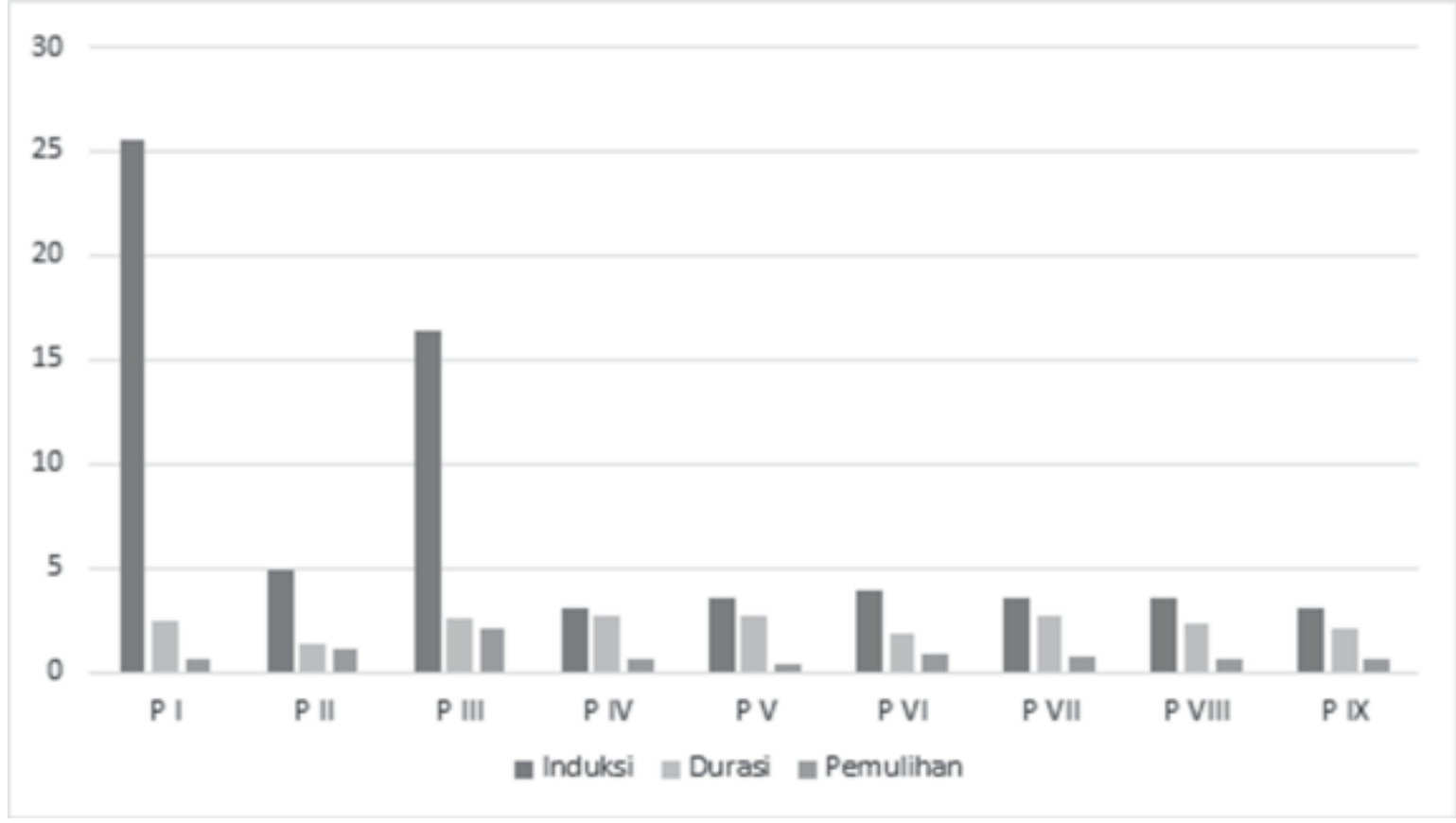

Gambar 1. Perbandingan waktu induksi, durasi, dan pemulihan anestesi pada ikan komet yang dianestesi dengan minyak cengkeh dan diemulsikan dengan kuning telur ayam kampung

$0,57 \pm 0,37 ; 0,40 \pm 0,10 ; 0,90 \pm 0,54 ; 0,77 \pm 0,55$ $0,59 \pm 0,04 ; 0,61 \pm 0,72$.

Berdasarkan hasil penelitian, masingmasing kelompok yang diberikan perlakuan menghasilkan efek anestesi dengan waktu induksi, durasi, dan pemulihan yang berbedabeda. Grafik perbandingan waktu induksi, durasi, pemulihan anestesi pada ikan komet disajikan pada Gambar 1.

Menurut Pongprayoon et al. (1991), bahan aktif eugenol yang terkandung dalam minyak cengkeh berfungsi menghambat sintesis prostaglandin $\mathrm{H}$ (PHS) yang menyumbang efek analgesik. Berdasarkan hasil penelitian, kelompok perlakuan I mampu menghasilkan efek anestesi, namun dengan waktu induksi yang lebih panjang dibandingkan dengan perlakuan lainnya. Hal ini disebabkan karena sulitnya minyak terdispersi dengan air sehingga penyerapan obat anestesi kedalam insang lambat. Anestesi yang ideal untuk ikan yaitu menghasilkan anestesi yang cepat (1-5 menit), sedangkan perlakuan minyak cengkeh dengan anestesi tunggal tidak memenuhi syarat tersebut. Untuk memenuhi kriteria anestesi ideal agar dapat digunakan untuk prosedur pembedahan, pemberian minyak cengkeh dapat ditambahkan emulsifier berupa kuning telur.

Kelompok perlakuan II hingga IX memiliki waktu induksi yang lebih cepat dibandingkan dengan kelompok perlakuan I. Hal ini sejalan dengan pernyataan Muchtadi (2010) bahwa kuning telur dapat digunakan sebagai bahan pengemulsi yang baik, sehingga menghasilkan waktu induksi yang lebih singkat. Menurut Anton et al. (2001), kuning telur adalah zat pengemulsi yang baik yang memiliki kesamaan seperti etanol 96\%. Hal ini dapat terjadi karena kandungan fosfatidilkolin (lesitin) kuning telur merupakan emulsifier yang lebih terikat pada air atau lebih larut dalam air (polar), sehingga dapat lebih membantu mendispersikan minyak dalam air dan terjadilah emulsi minyak dalam air (Setiawan, 2015). Selain itu, emulsifier mampu membentuk sebuah selaput tipis (film) di sekeliling butiran minyak yang terdispersi, sehingga dapat mencegah bersatunya kembali butir-butir tersebut (Winarno, 1997).

Jenis dan jumlah kuning telur dapat memengaruhi besarnya viskositas dan kekuatan emulsi (Weiss, 1983). Siregar (2012) menjelaskan bahwa semakin tinggi lesitin pada kuning telur maka semakin baik juga sifat kestabilan emulsi yang dihasilkan. Pada penelitian ini dapat dilihat bahwa hasil dari pemberian anestesi menggunakan minyak cengkeh yang dikombinasikan menggunakan kuning telur dapat mempercepat waktu induksi dan waktu yang dihasilkan ideal. Hal ini sejalan dengan pernyataan yang menyatakan bahwa obat 
anestesi yang ideal pada ikan dapat menghasilkan waktu induksi yang cepat (1-5 menit).

Menurut Endo et al. (1972) dosis minyak cengkih yang optimal untuk menginduksi anestesi pada $C$. arratus bervariasi antara 15,5100,0 ppm. Pada penelitian ini waktu induksi tersingkat adalah campuran Minyak Cengkeh (100 ppm) + Kuning telur (1,6 mL/L) menghasilkan waktu induksi $3,05 \pm 0,32$ menit dan Minyak Cengkeh (100 ppm) + Kuning telur (0,6 $\mathrm{mL} / \mathrm{L})$ menghasilkan waktu induksi 3.06 $\pm 0,32$ menit.

Rerata waktu pemulihan anestesi perlakuan I sampai dengan IX secara berurutan yaitu $0,61 \pm 0,34 ; 1,09 \pm 0,31 ; 2,14 \pm 0,71 ; 0,57 \pm 0,37$; $0,40 \pm 0,10 ; 0,90 \pm 0,54 ; 0,77 \pm 0,55 ; 0,59 \pm 0,04$; $0,61 \pm 0,72$. Hal tersebut sesuai dengan Pramono (2002), yang menyatakan bahwa waktu yang dibutuhkan ikan untuk pulih sadar dari kondisi pingsan yaitu di bawah 10 menit dari pulih, hingga melakukan gerakan renang normal.

\section{SIMPULAN}

Berdasarkan hasil penelitian yang telah dilakukan maka dapat disimpulkan bahwa kuning telur (emulsifier) dapat dikombinasikan dengan minyak cengkeh sebagai sediaan anestetik pada ikan komet, sama halnya seperti kombinasi minyak cengkeh dengan etanol 96\%. Waktu induksi tercepat yang didapat pada penelitian ini adalah 3,05 $\pm 0,32$ menit (Minyak Cengkeh (100 ppm) + Kuning telur (1,6 mL/L) sebagai anestesi pada ikan komet. Waktu durasi terpanjang serta pemulihan tercepat dihasilkan pada penggunaan kombinasi Minyak Cengkeh (100 ppm) + Kuning telur 0,8 mL/L.

\section{SARAN}

Berdasarkan hasil penelitian, penggunaan minyak cengkeh sebagai anestesi secara tunggal kurang disarankan karena menghasilkan waktu induksi yang lebih panjang. Kombinasi minyak cengkeh dan kuning telur ayam kampung lebih baik digunakan karena menghasilkan waktu induksi lebih cepat seperti halnya pada kombinasi minyak cengkeh dengan etanol 96\%. Selain itu, diperlukan penelitian lebih lanjut mengenai variasi konsentrasi minyak cengkeh yang digunakan, serta tingkat toksisitas anestesi kombinasi minyak cengkeh dengan kuning telur terhadap ikan komet.

\section{UCAPAN TERIMA KASIH}

Penulis mengucapkan terima kasih kepada Lab Ilmu Bedah Veteriner FKH Unud yang telah memberi ipenelitian, sehingga penelitian ini dapat diselesaikan dengan baik. Penulis juga mengucapkan terima kasih ke berbagai pihak yang dengan tulus ikhlas telah membantu dalam penelitian ini.

\section{DAFTAR PUSTAKA}

Akbulut B, Cakmak E, Aksungur N, Cavdar Y. 2011. Effect of exposure duration on time to recovery from anaesthesia of clove oil in juvenile of Russian sturgeon. Turk Journal Fish Aquat 11: 463-467.

Anton M, Le Denmat M, Beaumal V, Pilet P. 2001. Filler effects of oil droplets on rheology of heat-set emulsion gels prepared with egg yolk and egg yolk fractions. Colloids and Surfaces, B: Biointerfaces 21 (1-3): 137-147.

Bakal RS, Hickson BH, Gilger BC. 2005. Surgical removal of cataracts due to Diplostomum species in Gulf Sturgeon (Acipenser oxyrinchus desotoi). Journal Zoo Wildl Med 36: 504-508.

Brown RS, Cooke SJ, Wagner GN. 2010. Methods for surgical implantation of the acoustic transmitters in juvenile salmonids. Oak Ridge (TN): United States Department of Energy.

Endo M. 1972. Stretch-induced increase in activation of skinned muscle fibres by calcium. Nature New Biology 237(76): 211213.

Fischer IU, Unruh GE, Dengler HJ. 1990. The metabolism of eugenol in man. Xenobiotica. 20(2): 209-222.

Gilderhus PA, Marking LL. 1987. Comparative efficacy of 16 anesthetic chemicals on rainbow trout. NAm J Fish Manag 7: 288292.

Gomelsky B, Schneider KJ, Alsaqufi AS. 2011. Inheritance of Long Fins in Ornamental Koi Carp. North American Journal of Aquaculture 73: 49-52.

Gomulka P, Wlasow T, Velýsek J, Svobodova' Z, Chmielinska E. 2008. Effects of eugenol and MS-222 anaesthesia on siberian 
sturgeon acipenser baerii brandt. Acta Vet Brno 77: 447-453.

Harms CA. 2005. Surgery in Fish Research: Common Procedures and Postoperative Care. North Carolina State Univercity, USA. Lab Animal. 34(1).

Kismiyati, Kurnia SI, Kusnoto. 2012. Lama perendaman Ikan Komet (Carasius auratus auratus) dalam perasan Daun Pepaya (Carcia Papaya) sebagai Pengendali Argulus sp. Jurnal Ilmiah Perikanan dan Kelautan. 1(2): 6 .

Lewbart GA. 1998. Self-Assessment Colour Review of Ornamental Fish. London. Manson Publishing, Hlm. 192.

Lewbart GA, Stone EA, Love NE. 1995. Pneumatocystectomy in a Midas cichlid. Journal of the American Veterinary Association 207: 319-321

Lorenzoni M, Ghetti L, Pedicillo G, Carosi A. 2010. Analysis of the biological features of the goldfish (Carassius auratus auratus) in Lake Trasimeno (Umbria, Italy) with a view to drawing up plans for population control. Folia Zool 59(2): 142-156.

Muchtadi TR, Sugiyono, Ayustaningwarno F. 2010. Ilmu Pengetahuan Bahan Pangan. Cetakan Kedua. Bogor. CV Alfabeta. Hlm. 95-96

Munday PL, Wilson SK. 1997. Comparative efficacy of clove oil and other chemicals in anaesthetization of Pomacentrus amboinensis, a coral reef fish. Journal of Fish Biology 51(5): 931-938.

Murray MJ. 2002. Fish surgery seminars. Avian and Exotic Pet Medicine 11: 246-257.

Perdikaris C, Nathanailides C, Gouva E, Gabriel UU, Bitchava K, Athanasopoulou F, Paschou A, Paschos I. 2010. Size-relative effectiveness of clove oil as an anaesthetic for rainbow trout and goldfish. Oncorhynchus Mykissacta Veterinaria 79(3): 481-490.

Pongprayoon U, Baeckstrom P, Jacobsson U, Lindstrom M, Bohlin L. 1991. Compounds inhibiting prostaglandin synthesis isolated from Ipomoea pescaprae. Planta Med 57: $515-518$

Ross LG, Ross B. 1999. Anaesthetic and Sedative Techniques for Aquatic Animals. Oxford. Blackwell Science, Hlm. 159.
Setiawan AB. 2015. Pengaruh Penggunaan Berbagai Jenis Kuning Telur terhadap Kestabilan Emulsi, Viskositas, dan pH Mayonnaise. Students e-Journal 4(2). https://jurnal.unpad.ac.id/ejournal/article/ view/6255/3172

Siregar RF, Hintono A, Mulyani S. 2012. Perubahan sifat fungsional telur ayam ras pasca pasteurisasi. Animal Agriculture Journal 1(1): 521-528.

Soto CG, Burhanuddin S. 1995. Clove oil as a fish anaesthetic for measuring length and weight of rabbitfish (Siganus lineatus). Aquaculture 136: 149-152.

Spitsbergen JM, Tsai HW, Reddy A, Miller T, Arbogast D, Hendrick JD, Bailey GS. 2000. Neoplasia in Zebrafish (Danio rerio) treated with 7,12-Diniethylbenz- a-anthracene by two exposure routes at diYerent developmental stages. Toxicologic Pathology 28: 705-715.

Szczerbowski J.A. 2002. Carassius auratus (Linnaeus, 1758). In: The freshwater fishes of Europe, Cyprinidae 2, Part III: Carassius to Cyprinus (Banarescu PM, Paepke HJ Eds). Wiebelsheim. AULA-Verlag, Hlm. 541.

Wahyuningsih S, Khaerul M, Bagus DHS. 2012. Pengaruh jenis substrat penempel telur terhadap tingkat keberhasilan pemijahan ikan mas koki komet (Carassius auratus). Jurnal Perikanan Unram 5: 10-15.

Weiss TJ. 1983. Food Oils and Their Uses. 2nd Edition. Westport. Connecticut AVI Publishing Company, Inc..Hlm. 213

Winarno, F.G. 1997. Kimia Pangan dan Gizi. Penerbit PT. Gramedia Pustaka Utama, Jakarta.

Zahl HI, Samelsen O. 2012. Anaesthesia of Farmed Fish: Implications for Welfare. Fish Physiol Biochem 38: 201-218.

Zhou Z, Cui Y, Yang Y. 2001. Growth and feed utilization in two strains of gibel carp, Carassius auratus gibelio: paternal effects in a gynogenetic fish. J Appl Ichthyol 17: 54-58. 